\title{
A proposed crinoid zonation of the Devonian deposits of eastern Transbaikal
}

\author{
ALENA V. KURILENKO \& NIKOLAY P. KULKOV
}

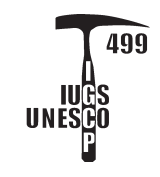

\begin{abstract}
Devonian deposits of eastern Transbaikal, Russia, are widely distributed in the Onon, Argun and Upper Amur terranes, each with a different geological development history. Two lithofacies are represented in the geological section: carbonate-volcanogenic-terrigenous (Onon terrane) and terrigenous-carbonate (Argun and Upper Amur terranes), with strata in the latter characterized by abundant fossil remains, especially numerous crinoids and brachiopods. Brachiopod assemblages are stated for each strata of the Transbaikal Devonian. A crinoid biostratigraphic zonation is proposed within the Mongol-Okhotsk fold belt as follows: Scyphocrinites mariannae, Costatocrinus bicostatus and Tastjicrinus paucicostatus (Lower Lochkovian); Amazaricrinus ildicanensis (Pragian); Paradecacrinus orientalis (Emsian); Raricrinus minimus and Vasticrinus vastus (Eifelian); Ononicrinus gracilis (Givetian); Hexacrinites? stukalinae sp. nov. (Frasnian) and Platycrinites? subtuberosus (Upper Famennian). Local and regional crinoid ages accord well with those of brachiopods. Lateral distribution of faunal assemblages allows regional correlation. - Keywords: Devonian, crinoid biozonation, brachiopods, assemblages, biostratigraphy, Transbaikal.
\end{abstract}

KURILENKO, A.V. \& KULKOV, N.P. 2008. A proposed crinoid zonation of the Devonian deposits of eastern Transbaikal. Bulletin of Geosciences 83(4), 461-472 (4 figures, 2 tables). Czech Geological Survey, Prague. ISSN 1214-1119. Manuscript received November 22, 2006; accepted in revised form July 2, 2008; issued December 31, 2008.

Alena Vasilyevna Kurilenko, State Geological Unitary Enterprise “Chitageolsyomka”, Amurskaya St. 91/15, 672090 Chita, Russia; Alena_Kurilenko@geolog.chita.ru・Nikolay Petrovich Kulkov, Siberia Research Institute of Geology, Geophysics and Mineral Resources, 630091 Novosibirsk, Russia

Southeastern Transbaikal in far eastern Russia extends from west to east from the middle reaches of the Onon River to the upper reaches of the Amur River. Devonian deposits are widely distributed in the Onon, Argun and Upper Amur terranes, each having a different geological development history (Figs 1, 2).

The Onon terrane formations are dominated by carbonate-volcanogenic-terrigenous deposits of a deep-water backarc basin. The Argun and Upper Amur terranes are composed of limestone, sandstone and aleurolite and were deposited in the shelf zone of a paleobasin. Faunal remains are not numerous in the Onon terrane. In the Argun and Upper Amur terranes all strata are characterized by abundant fossil remains. Crinoids and brachiopods are very numerous.

R.S. Yeltysheva was studying small collections of crinoids from Transbaikal in the 50-60 years of the $20^{\text {th }}$ century (e.g., 1956, 1969). The first taxa were determined from the lower part of Ildikan Suite in the basin of the Gazimur River. Those from the Early Devonian comprise: Pentagonocyclicus delenificus Yeltysheva, Decacrinus orientalis (Yeltysheva), Kuzbassocrinus decemlobatus Yeltysheva, Cyclocyclicus bohemicus Yeltysheva and Cycloellipticus corneus Yeltysheva. The Middle Devonian assemblage from the up- per Ildikan Suite includes: Pentagonocyclicus vastus Yeltysheva \& J. Dubatolova, P. arboriformis Yeltysheva, $P$. orientalis Yeltysheva and Cyclocyclicus subcrenatus Yeltysheva (Tichomirov 1960). In addition, Middle Devonian crinoids Hexacrinites? ex. gr. mamillatus Yeltysheva \& J. Dubatolova, H.? biconcavus Yeltysheva \& J. Dubatolova, Pentagonopentagonalis ex gr. floreus Yeltysheva and Pentagonocyclicus cf. radialis Yeltysheva were identified by Yeltysheva from the Yakovlev Suite on the left bank of the Onon River and Pentagonocyclicus ex gr. circumvallatus Yeltysheva and Platycrinites? sp. from the Yakovlev Suite on the left bank of the Argun River (in Nalivkin et al. 1973). Yeltysheva also studied crinoids from the Bolshoi Never Suite of the Upper Priamur district: Decacrinus orientalis (Yeltysheva), Hexacrinites cf. biconcavus Yeltysheva \& J. Dubatolova and Pentagonopentagonalis radialis Yeltysheva; from the Oldoy Suite: Cyatocrinus mamillatus Yeltysheva and Entrochus dentatus Quenstedt, and from the Teplovskii Suite: Hexacrinites? sp. and Pentagonocyclicus aff. imatschensis Yeltysheva \& J. Dubatolova, matched by Modzalevskaya.

The first monographic treatments of Devonian crinoids from the Transbaikal was made by Dubatolova and Yeltysheva (Dubatolova et al. 1967, Yeltysheva 1969), in 


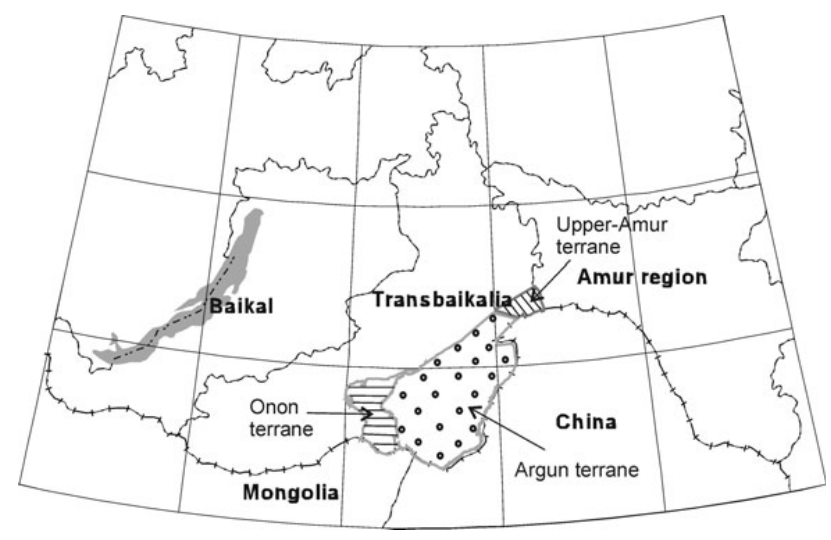

Figure 1. Scheme of terranes in the Transbaikal region.

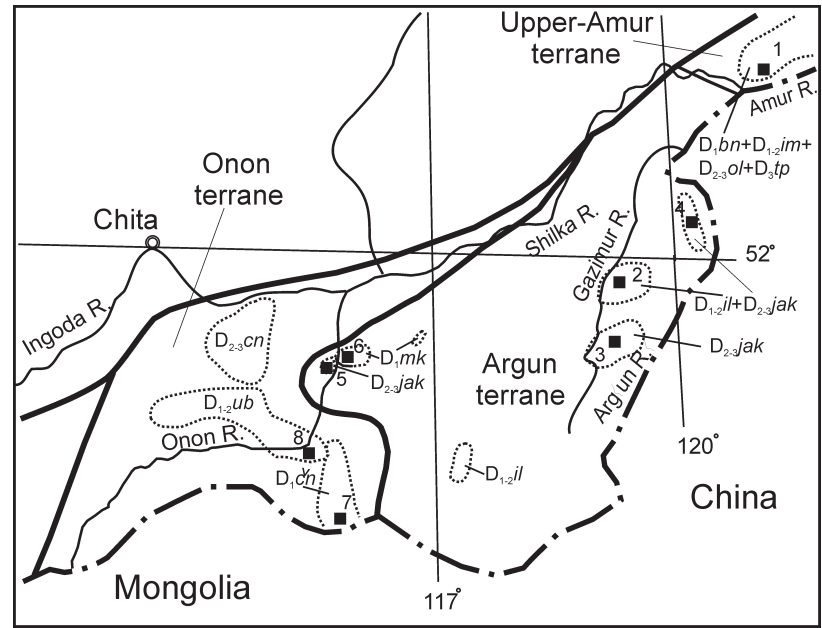

Figure 2. Scheme of Devonian strata in the Transbaikal region. A - position of fauna: 1 - Upper Priamur; 2 - Gazimur River; 3 - Klichka Mountain; 4 -Argun River; 5 - Onon River, the left bank; 6 - Onon River, the right bank; 7 - the railway station Durbachi; 8 - Ust-Borzya village, $\mathrm{B}$ - the Devonian section of the Onon terrane: $\mathrm{D}_{1} \breve{\mathrm{c}}$ - Chindant Suite; $\mathrm{D}_{2-3} \mathrm{ub}$ - Ustborzya Suite; $\mathrm{D}_{3} \mathrm{cn}$ - Tsagan-Nor Suite; the Devonian section of the Argun terrane: $\mathrm{D}_{1} \mathrm{mk}$ - Makarov Unit; $\mathrm{D}_{1-2}$ il - Ildikan Suite; $\mathrm{D}_{2-3}$ jak - Yakovlev Suite; the Devonian section of the Upper-Amur terrane: $D_{1}$ bn - Bolchoi Never Suite; $D_{1-2}$ im - Imachi Suite; $\mathrm{D}_{2-3} \mathrm{Ol}$ - Oldoy Suite; $\mathrm{D}_{3} \mathrm{tp}-$ Teplovskii Suite.

which the following species were described: Hexacrinites? dentatus echinatus Yeltysheva \& J. Dubatolova, H.? biconcavus Yeltysheva, H.? mamillatus Yeltysheva \& J. Dubatolova, Entrochus dentatus Quenstedt, Decacrinus orientalis (Yeltysheva), D. aff. pennatus Yeltysheva, Kuzbassocrinus decemlobatus Yeltysheva, Anthinocrinus floreus Yeltysheva, A. raricostatus Yeltysheva \& J. Dubatolova and Pentagonocyclicus vastus Yeltysheva \& J. Dubatolova.

During the last 25 years the senior author has been studying crinoid stem remains, using the systematic method of Stukalina (1964) and Moore et al. (1968) revising all material of the abundant stem fragments from the
Devonian strata of eastern Transbaikal. The nomenclature and systematic position of 64 species, including those originally identified by Yeltysheva and Dubatolova are here proposed in modern nomenclature. Identification of the assemblages has allowed more refined definition of the age of numerous strata.

Here we present new information from continuing investigations of Devonian stratigraphy and paleontology in the Transbaikal and summarize previous stratigraphic and paleontological data (Luchickiy 1954, Modzalevskaya 1958, Tichomirov 1960, Amantov 1963, Anashkina et al. 1997, Popeko 2000).

\section{Results of investigations}

\section{Devonian of Onon terrane}

Middle Paleozoic deposits of the Onon terrane (Figs 1, 2) are comparatively homogeneous in lithological composition. They are characterized by infrequent fossil-bearing horizons and are divided into blocks with multiple-folded structures. The Devonian Chindant, Ustborzya and Tsagan-Nor suites were recognized (Turbin 1994) in an up-todate stratigraphic scheme (Table 1) based on the rhythmostratigraphic principle.

These suites make up a continuous series between the underlying Kulinda (O-S?) and Onon (S?) suites and the overlapping Zhun-Shevija $\left(\mathrm{D}_{3}-\mathrm{C}_{1}\right)$ Suite. The age of the Chindant Suite is based on rare occurrences of the rugose coral Embolophyllum mansfieldense (Duncan), which ranges from the Lochkovian to the beginning of the Pragian in one small tectonic block in the southeastern part of the terrane (Anashkina et al. 1997). We date the Ustborzya Suite as Middle to Late Devonian (Early Frasnian) based on the discovery (L. Nebericutina identification) in the upper part of the section of spores of the Late Givetian-Early Frasnian: Archaeozonotriletes mutatus Naumova, A. timanicus Naumova, Leiotriletes parvus Naumova, Trachytriletes pussilus Naumova, Hymenozonotriletes primitivus Raskazova, Lophozonotriletes forosus Raskazova, Lophotriletes grumosus Naumova, L. perpusillus Naumova, among others; Late Silurian-Devonian coral ?Alveolites sp. (B. Sokolov identification); and Middle Devonian-Early Frasnian crinoid ?Vasticrinus sp. (R. Yeltysheva identification). The stratigraphic location of the Tsagan-Nor Suite between the Ustborzya and Zhun-Shevija suites defines its age conventionally as Middle Frasnian-Middle Famennian. The lower part of the Zhun-Shevija Suite is characterized by the brachiopod Cyrtospirifer ex gr. verneuili Murchison, dating from Late Frasnian to Famennian and crinoids Bicostulatocrinus circumvallatus (Yeltysheva) and Pentaridica pulcher (Yeltysheva), which appear in the Late Famennian (Popeko 2000). 


\section{Devonian of Argun and Upper Amur terranes}

In the Devonian of the Argun terrane, the Lochkovian Makarov Unit, Pragian and Eifelian Ildikan Suite and Givetian-Famennian Yakovlev Suite are present in small grabens that occur from the Onon estuary in the west to the basin of the middle Argun stream in the east (Fig. 2) (Tichomirov 1960, Kurilenko et al. 2001, Kurilenko et al. 2002). In the Upper Priamur, a complete Devonian section is represented by the Bolshoi Never, Imachi, Oldoy and Teplovskii suites between the subjacent Silurian Omutnaya Suite and superjacent Tournaisian-Lower Visean Tipara Suite (Modzalevskaya 1958, Anashkina et al. 1997) (Table 1). All strata contain abundant characteristic paleontological remains. Brachiopods (studied by N.K.) and crinoids (A.K. worked out biostratigraphic ranges), provide age determination of strata within the Argun and Upper Amur terranes (Kurilenko et al. 2002) (see Table 2). The lateral distribution of the faunal complexes allows correlation with other regions.

\section{Fauna of Devonian deposits of Argun and Upper Amur terranes}

In the Makarov Unit of the Argun terrane and the lower part of the Bolshoy Never Suite of the Upper Priamur, the Scyphocrinites mariannae Biozone is recognized and overlain by what Biozone with Costatocrinus bicostatusTastjicrinus paucicostatus (Table 2, Fig. 3). They are components of the lower part of the Bolshoi Never Horizon. The $S$. mariannae Beds correlate with the boundary layers of the Skal and Borschov horizons in the southwestern part of the East-European platform, which are dated by the occurrence of the graptolite Monograptus uniformis angustidens Prribyl, known from the Silurian to Devonian boundary layers of northern France, Germany, Poland, Bulgaria, Czech Republic, China and Morocco and the lower part of the Pennatocrinus subpennatus-Scyphocrinites zone in the Ainasui Horizon of Kazakhstan. The discovery of Scyphocrinites provides the first evidence to determine the Silurian-Devonian boundary interval in Transbaikal (Kurilenko et al. 2001).

Beds with Costatocrinus bicostatus-Tastjicrinus paucicostatus are coeval with the upper part of the Pennatocrinus subpennatus-Scyphocrinites zone and Decacrinus ovalis-Podoliocrinus nikiforovae zone (Kokbaital Horizon) of Kazakhstan. The occurrence of $C$. bicostatus (Stukalina) correlates with the Kunzhak and Shishkat horizons of the Zeravshano-Gissarskaya mountainous region of southern Tian-Shan, the Anthinocrinus radialis (Stukalina)-bearing Mitkov Beds of the Borschov Horizon of the East-European platform and Mediocrinus medius (Yeltysheva), Gurjevskocrinus impalpabilis J. Dubatolova
Table 1. Correlation of Devonian deposits of the Onon, Argun and Upper Amur terranes

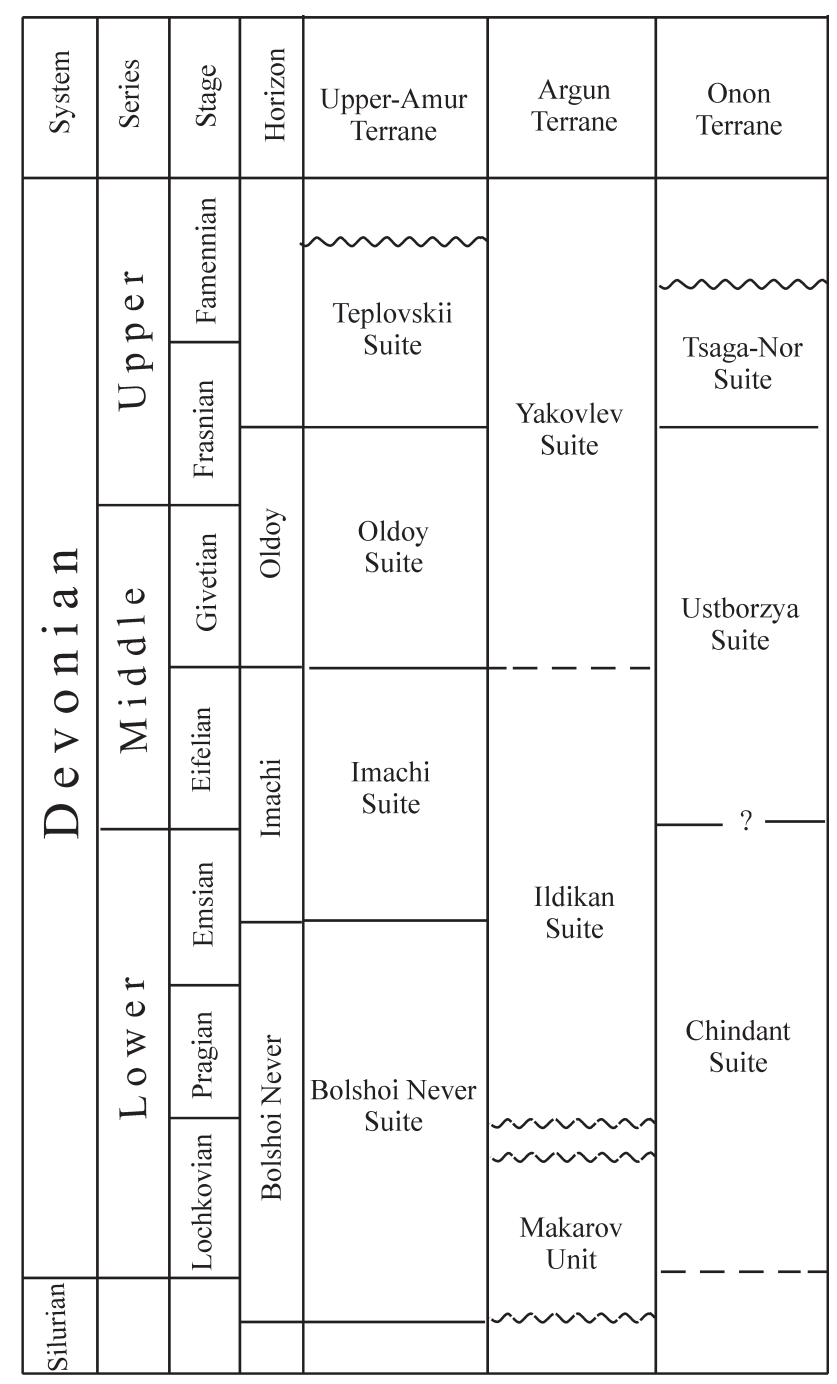

and Costatocrinus bicostatus (Stukalina)-bearing Tom'chumysh Horizon of the Salair. The beds distinguished in the Transbaikal and Sarajnaya and Sauma horizons in the Urals are also considered coeval because of the occurrence of the genera Costatocrinus and Mediocrinus (Stukalina 1986, 1991).

The brachiopods Dalejina austera Havlíček, Plectodonta mimica (Barrande) and Lissatrypa sp. co-occur with crinoids in the lower parts of the Bolshoi Never Suite. Dalejina austera and Plectodonta mimica are found in the Lochkovian stage of the Barrandian. The latter is characteristic of the coeval level of Podolia and China but in Germany it is also considered to be in the Pragian stage. Lissatrypa sp. is close to a species from the Lochkovian of Podolia and Australia. Thus these brachiopods most likely characterize the Lochkovian of the surrounding rocks (Barrande 1879, Boucot et al. 1965, Havlíček 1977, Jahnke \& Shi Yan 1989). 
The lower part of the Ildican Suite of the Argun terrane and the middle part of the Bolshoi Never Suite of the Upper Priamur contain horizons with Amazaricrinus ildicanensis (Table 2, Fig. 3). Amazaricrinus minimus (Stukalina), Kuzbassocrinus decemlobatus Yeltysheva, Pandocrinus grandis Kurilenko, Anthinocrinus primaevus Sisova, Urushicrinus ržonsnickae Kurilenko, rare Kuzbassocrinus binidigitatus Yeltysheva, Tastjicrinus cf. tastjiensis Stukalina, Paradecacrinus cf. decemcrassus (J. Dubatolova), Shishkinaecrinus partitus Kurilenko, Facetocrinus minusculus Kurilenko, Imatschicrinus ivanovi (Yeltysheva \& J. Dubatolova), Hexacrinites? biconcavus Yeltysheva \& J. Dubatolova, H.? mamillatus Yeltysheva \& J. Dubatolova, Asperocrinus dentatus (Quenstedt), Amurocrinus cf. imatschensis (Yeltysheva \& J. Dubatolova), and Graptocrinus incelebratus (Yeltysheva \& J. Dubatolova) are also found in association with the most abundant index-species. Kuzbassocrinus decemlobatus and Amazaricrinus are extremely characteristic for the Pragian sections of numerous Russian regions. They allow correlation of the strata with the Maly Bachat Horizon of the northeastern Salair, the Yakushinsk Horizon of the Gorny Altai, and the Pandzhrut Horizon of the southern Tian-Shan, Vizhai and Toshemka horizons of the eastern Ural slope (Schewtshenko 1966, Dubatolova et al. 1967, Dubatolova 1971, Stukalina 1986).

These same strata contain a rich complex of brachiopods. Typical species of Pragian age in these deposits are: Prokopia sp., Isorthis cf. quadrata Alekseeva, I. inostranzewi (Peetz), Rhytistropia beckii (Hall), Areostrophia distorta (Barrande), Caplinoplia embyo (Barrande), Notanoplia sp., and Eucharitina subspeciosa (Modzalevskaya). Isorthis inostranzewi is widely known in the Lochkovian and Pragian deposits of Gorny Altai, Salair and West Siberian plate (Gracianova 1967, Kulkov \& Peregoedov 1990); Rhytistropia beckii is characteristic of the Pragian stage of North America, Mongolia and Kazakhstan (Johnson 1970, Kaplun 1961, Chernysheva 1937); Areostrophia distorta is widespread in the Pragian and lower parts of Emsian stage of the Barrandian, Gorny Altai, and Salair (Havlíček 1967, Gracianova 1967); Caplinoplia embyo is distributed in the Pragian stage of the Barrandian, Gorny Altai, West-Siberia plate, and possibly in Germany (Gracianova 1967, Kulkov \& Peregoedov 1990); Notanoplia occurs in the Pragian stage of Gorny Altai (Gracianova 1967); Eucharitina subspeciosa (Modzalevskaya) is known from the Pragian of the Mongolia and Transbaikal (Alekseeva et al. 1981, Kulkov in Kurilenko et al. 2002). Also found in the layers with crinoids and brachiopods are corals Riphaeolites ramosus Yanet, $R$. virgosus Yanet, Favosites porfirievi Chernyshev var. oldoica J. Dubatolova, Lyrielasma denticulata Zheltonogova, and the trilobite Paciphacops sp. (Kurilenko et al. 2002).

Paradecacrinus orientalis, characteristic of the Emsian, has not been found in the Argun terrane but is present in the Upper Amur terrane where it is found in the upper part of the Bolshoy Never and lower part of the Imachi suites (upper Bolshoy Never and lower Imachi horizons) (Figs 2, 3, Table 2). Crinoids are also present in these horizons, as follows: Paradecacrinus orientalis (Yeltysheva), Kuzbassocrinus binidigitatus Yeltysheva (epibole), Urushicrinus eugeniae (Yeltysheva \& J. Dubatolova), U. raricostatus (Yeltysheva \& J. Dubatolova), Anthinocrinus primaevus Sisova, Asperocrinus dentatus (Quenstedt), Imatschicrinus ivanovi (Yeltysheva \& J. Dubatolova), Graptocrinus incelebratus (Yeltysheva \& J. Dubatolova), Hexacrinites? biconcavus Yeltysheva \& J. Dubatolova, H.? torulosus J. Dubatolova, rare H.? mamillatus Yeltysheva \& J. Dubatolova, Amurocrinus imatschensis (Yeltysheva \& J. Dubatolova). The occurrence of the same or similar species allows us to correlate these horizons with Emsian deposits of the Gorny Altai: Paradecacrinus orientalis, Kuzbassocrinus binidigitatus, Urushicrinus raricostatus, Anthinocrinus primaevus, Hexacrinites? torulosus. There are also species in common with the Salairka Horizon of northeastern Salair (Kuzbassocrinus binidigitatus, Anthinocrinus primaevus) and the Sardzhal and Kazakh horizons of Kazakhstan (Urushicrinus eugeniae, Anthinocrinus primaevus) (Dubatolova et al. 1967; Dubatolova 1971; Stukalina 1986, 1991).

Brachiopods occurring with crinoids in the lower part of the Imachi Suite mentioned above are identified as: Reeftonia borealis (Hamada), Schizophoria cf. kobajashii (Hamada), Leptaenopyxis cf. bouei (Barrande), Leptostrophia cf. kharkraica N. Chernysheva, Xystostrophia sp., Douvillina cf. nalivkini (Khalfin), Chonetes sp., Wilsoniella cf. prima (Khalfin), Acrospirifer cf. korovini (Khalfin), Leptodontella zmeigorskiana (Peetz), Rotundostrophia cf. rotundata (Khalfin), Maoristrophia kailensis Schischkina, Leptogonia zlichovensis (Havlíček) and Paraspirifer urcanensis Modzalevskaya. The largest number of species are in common between this horizon and the Emsian of Gorny Altai (Leptaenopyxis bouei, Xystostrophia sp., Douvillina cf. nalivkini, Wilsoniella cf. prima, Acrospirifer cf. korovini, Rotundostrophia cf. rotundata, Leptogonia zlichovensis among others) and Salair (Leptaenopyxis bouei, Leptodontella zmeigorskiana, Leptogonia zlichovensis). Also, there are species in common with the Emsian strata of the West-Siberia plate (Xystostrophia sp.), Kazakhstan (Leptaenopyxis bouei); Rudny Altai (Leptodontella zmeigorskiana); and the Far East (Leptodontella zmeigorskiana, Rotundostrophia cf. rotundata). In addition, Reeftonia borealis and Schizophoria kobajashii are identified from the Khulanmen Formation of Maly Khingan; Leptogonia zlichovensis was reported by Havlíček (1977) from the base of the lower Emsian Zlikhov limestones of the Barrandian; and Leptostrophia kharkraica and Wilsoniella prima are 
Table 2. The distribution of crinoids and brachiopods associations in Devonian deposits of Transbaikal. Abbreviations: AT - Argun terrane, UAT - Upper Amur terrane, C.-T. - Costatocrinus bicostatus-Tastjicrinus paucicostatus

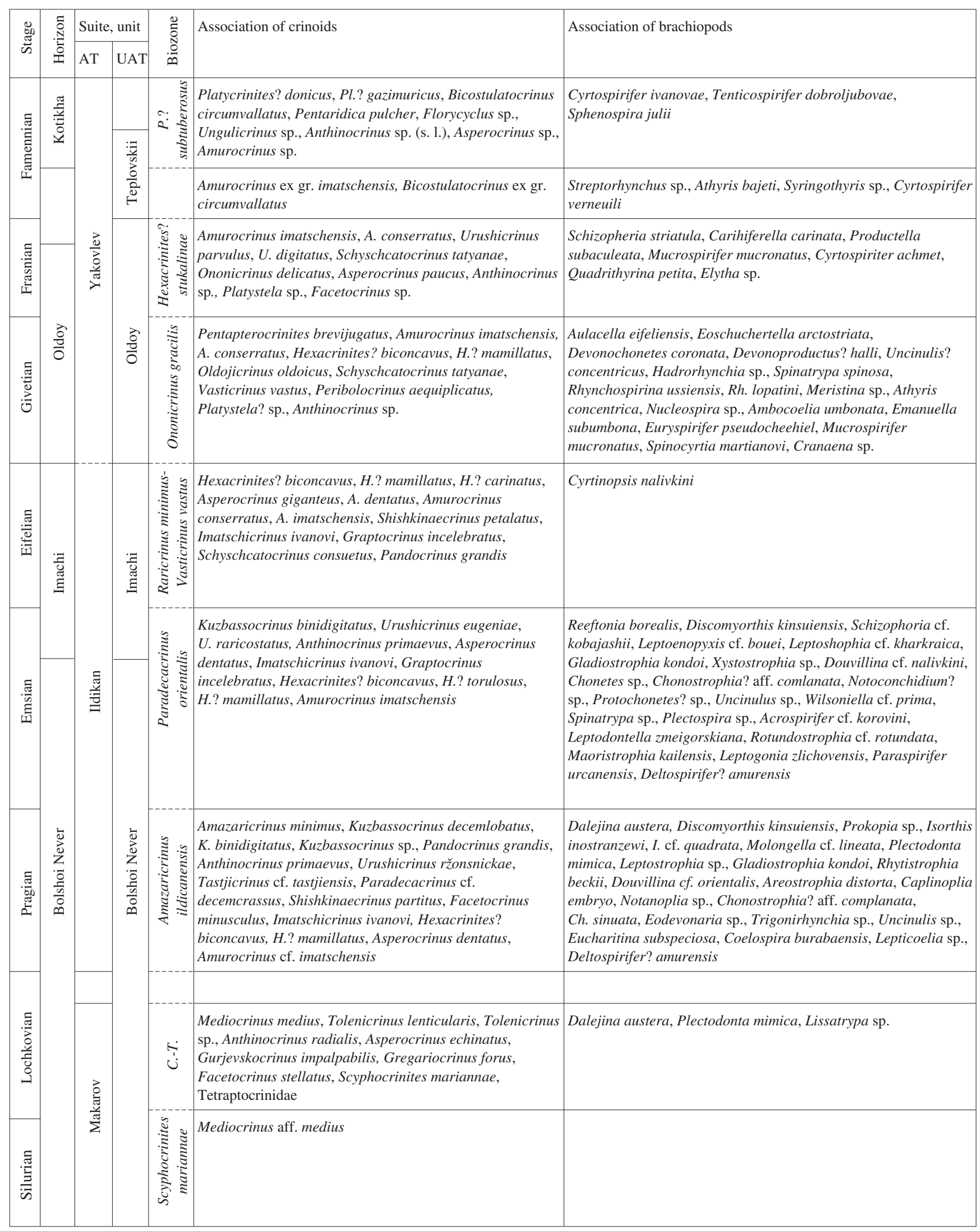


known from the Lower Devonian of Mongolia (Khalfin 1939, 1948; Chernysheva 1937; Gracianova 1975; Kulkov \& Pergoedov 1990; Kurilenko et al. 2002). The age of deposits with Paradecacrinus orientalis, according to brachiopods is undoubtedly Emsian.

The Raricrinus minimus-Vasticrinus vastus Biozone corresponds to the upper parts of the Ildikan and Imachi suites (upper Imachi Horizon) (Figs 2, 3, Table 2). The typical assemblage comprises Raricrinus minimus (Yeltysheva \& J. Dubatolova), Vasticrinus vastus (Yeltysheva \& J. Dubatolova), Hexacrinites? biconcavus Yeltysheva \& J. Dubatolova, H. ? mamillatus Yeltysheva \& J. Dubatolova, H.? carinatus Yeltysheva \& J. Dubatolova, H.? humilicarinatus Yeltysheva, Asperocrinus giganteus Stukalina, A. dentatus (Quenstedt), Amurocrinus conserratus (Yeltysheva \& J. Dubatolova), A. imatschensis (Yeltysheva \& J. Dubatolova), Shishkinaecrinus petalatus (Yeltysheva \& J. Dubatolova), Imatschicrinus ivanovi (Yeltysheva \& J. Dubatolova), Graptocrinus incelebratus (Yeltysheva \& J. Dubatolova), Schyschcatocrinus consuetus J. Dubatolova, Pandocrinus grandis Kurilenko, and Pestericrinus sp. In this stratigraphic interval there are no members of the families Paradecacrinidae, Kuzbassocrinidae, Anthinocrinidae, which are characteristic of the Pragian and Emsian stages in Transbaikal and the Far East. Raricrinus minimus and Shishkinaecrinus petalatus are known from the Eifelian of the Far East. Hexacrinites? carinatus, occurring in this assemblage, is the key for correlating these deposits with the Upperlosishino Subsuite of the Rudny Altai and the Mamontovo Horizon of Salair. Representatives of the genus Pestericrinus are characteristic of the Eifelian of the Rein region as well as the Emsian-Eifelian of regions of the Arctic, the eastern slope of the Urals, Salair and southern Tian-Shan (Dubatolova et al. 1967, Yeltysheva 1969, Dubatolova 1971, Stukalina 1986).

The brachiopods Cyrtinopsis nalivkini Rzhonsnitskaya (E. Modzalevskaya identification) are found in limestones of the upper part of the Ildikan Suite. They are characteristic for Emsian deposits of numerous regions of Russia (Rzhonsnitskaya 1952, Zanina \& Likharev 1975).

The Ononicrinus gracilis Biozone within the lower part of the Oldoy Horizon is also the lower part of the Yakovlev and the Oldoy suites (Figs 2, 4, Table 2), beds dated as Givetian. In addition to the index-species Pentapterocrinites brevijugatus J. Dubatolova, Amurocrinus imatschensis (Yeltysheva \& J. Dubatolova), A. conserratus (Yeltysheva \& J. Dubatolova), Hexacrinites? biconcavus Yeltysheva \& J. Dubatolova, H.? mamillatus Yeltysheva \& J. Dubatolova, Oldojicrinus oldoicus (Yeltysheva \& J. Dubatolova), Schyschcatocrinus tatyanae Kurilenko, Vasticrinus vastus (Yeltysheva \& J. Dubatolova), Peribolocrinus aequiplicatus (Yeltysheva \& J. Dubatolova) and Platystela? sp. are present at this level. The index-species itself is widespread in Givetian strata of the Upper Priamur, the Zeisko-Depsky district (lower Oldoy Suite), Gorny Altai (Belgebasch Suite), the Urals (Vysotino Horizon), Mongolia, and Poland. Similar forms have been described from coeval deposits in North America (Dubatolova et al. 1967; Yeltysheva 1969; Dubatolova 1971, 1982; Stukalina 1986; Kurilenko et al. 2002).

The brachiopods Devonoproductus? halli (Modzalevskaya), ?Athyris concentrica (Buch), Euryspirifer pseudo-

Figure 3. A, H, P-Amazaricrinus ildicanensis Kurilenko, 2001. A-exemplar 12/10900, ×5; P-exemplar 25/13038, × 7; articular facets of a proximal columnals. Amur River. Lower Devonian, Beds with Amazaricrinus ildicanensis. H - exemplar 2/12704, $\times 4$; articular facet of a proximal columnal. Transbaikal, Gazimur River. Lower Devonian, Beds with Amazaricrinus ildicanensis. • B - Pandocrinus grandis Kurilenko, 2001. Holotype 4/12704, $\times 2$; articular facet of a distal columnal. Transbaikal, Gazimur River. Lower Devonian, Beds with Amazaricrinus ildicanensis. $\bullet$ C - Vasticrinus vastus (Yeltysheva \& J. Dubatolova, 1960). Exemplar 122/13038, × 1.2; lateral view of a pluricolumnal. Transbaikal, Gazimur River. Middle Devonian, Beds with Raricrinus minimus-Vasticrinus vastus. $\bullet$ D, N, Q - Scyphocrinites mariannae Yakovlev, 1953. D - exemplar 88/13038, $\times 4.5$; articular facet of a columnal. Transbaikal, Onon River. Lower Devonian, Beds with Costatocrinus bicostatus-Tastjicrinus paucicostatus. N - exemplar 90/13038, $\times$ 6; Q - exemplar 91/13038, × 5; articular facets of the columnals. Transbaikal, Onon River. Lower Devonian, Beds with Scyphocrinites mariannae. - E, J - Kuzbassocrinus binidigitatus Yeltysheva, 1957. E - exemplar 61/9597, × 7; J - exemplar from collection 9597, × 11; articular facets of the proximal columnals. Far East, Amur River. Lower Devonian, Beds with Paradecacrinus orientalis. $\bullet$ F - Costatocrinus bicostatus (Stukalina, 1961). Exemplar 18/13038, × 4; articular facet of a columnal. Transbaikal, Amur River. Lower Devonian, Beds with Costatocrinus bicostatus-Tastjicrinus paucicostatus. $\bullet$ G-Raricrinus minimus (Yeltysheva \& J. Dubatolova 1967). Exemplar 138/13038, × 15; articular facet of a proximal columnal. Transbaikal, Amur River. Middle Devonian, Beds with Raricrinus minimus-Vasticrinus vastus. $\bullet$ I - Kuzbassocrinus decemlobatus Yeltysheva, 1957. Exemplar 8/12704, $\times 4.5$; articular facet of a proximal columnal. Transbaikal, Amur River. Lower Devonian, Beds with Amazaricrinus ildicanensis. $\bullet \mathrm{K}-$ Amazaricrinus minimus (Stukalina, 1977). Exemplar 42 /13038, × 10; articular facet of a proximal columnal. Transbaikal, Amur River. Lower Devonian, Beds with Amazaricrinus ildicanensis. • L - Urushicrinus ržonsnickae Kurilenko, 2002. Not the actual specimen. Holotype 49/13038, $\times 9.5$; articular facet of a proximal columnal. Transbaikal, Amur River. Lower Devonian, Beds with Amazaricrinus ildicanensis. $\bullet$ M - Shishkinaecrinus partitus Kurilenko, 2002. Not the actual specimen. Holotype $61 / 13038, \times 7$; articular facet of a proximal columnal. Transbaikal, Amur River. Lower Devonian, Beds with Amazaricrinus ildicanensis. $\bullet \mathrm{O}-$ Hexacrinites? mamillatus Yeltysheva \& J. Dubatolova, 1960. Exemplar 74/13038, × 5; articular facet of a proximal columnal. Transbaikal, Amur River. Lower Devonian, Beds with Amazaricrinus ildicanensis. $\bullet \mathrm{R}-$ Paradecacrinus orientalis (Yeltysheva, 1957). Exemplar 15/10900, × 3.5; articular facet of a proximal columnal. Far East, Amur River. Lower Devonian, Beds with Paradecacrinus orientalis. Type species stored in the Central Science-Research Geological Exploration Museum named after Academician F.N. Chernyshev (CNIGR Museum), St. Petersburg. 

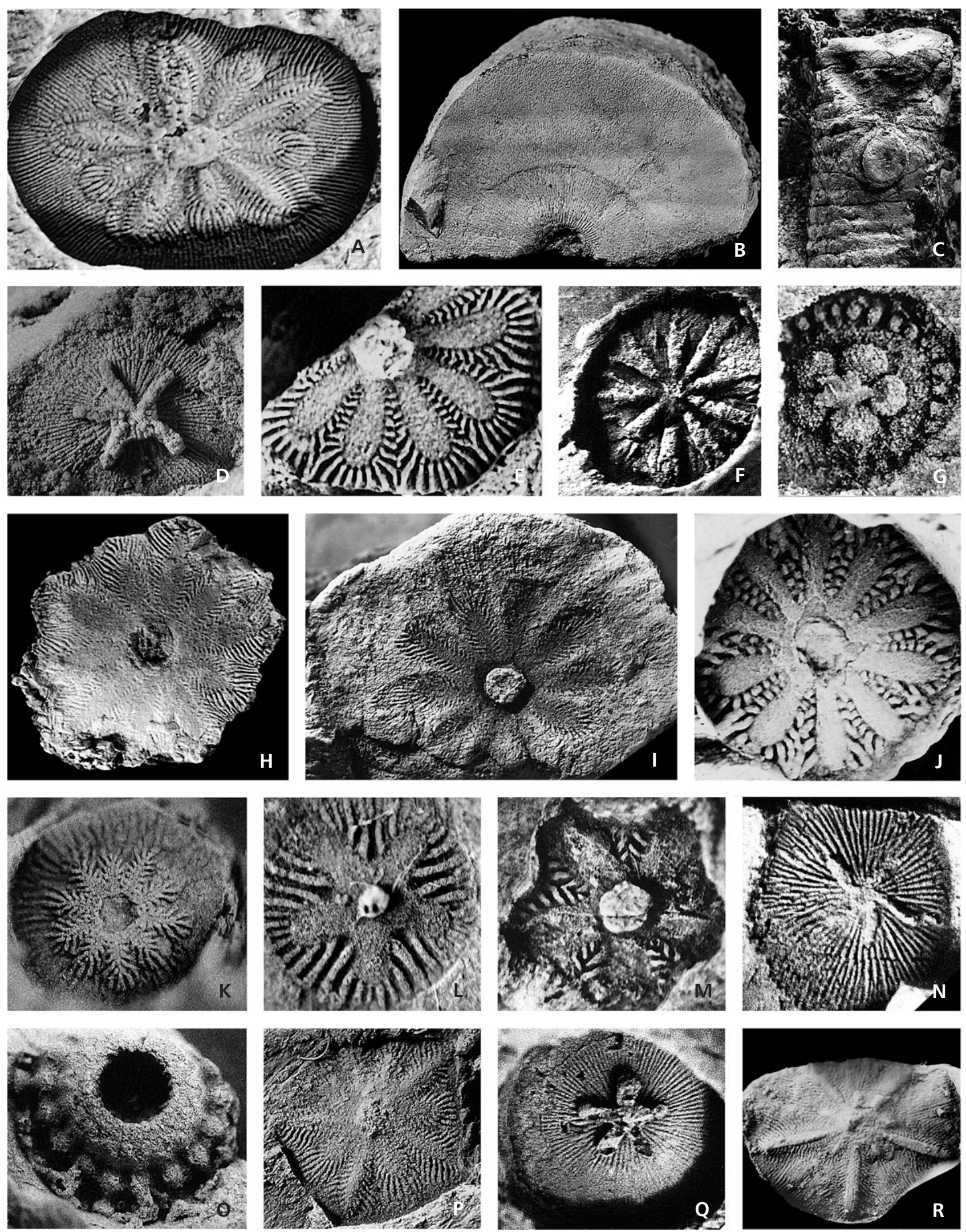

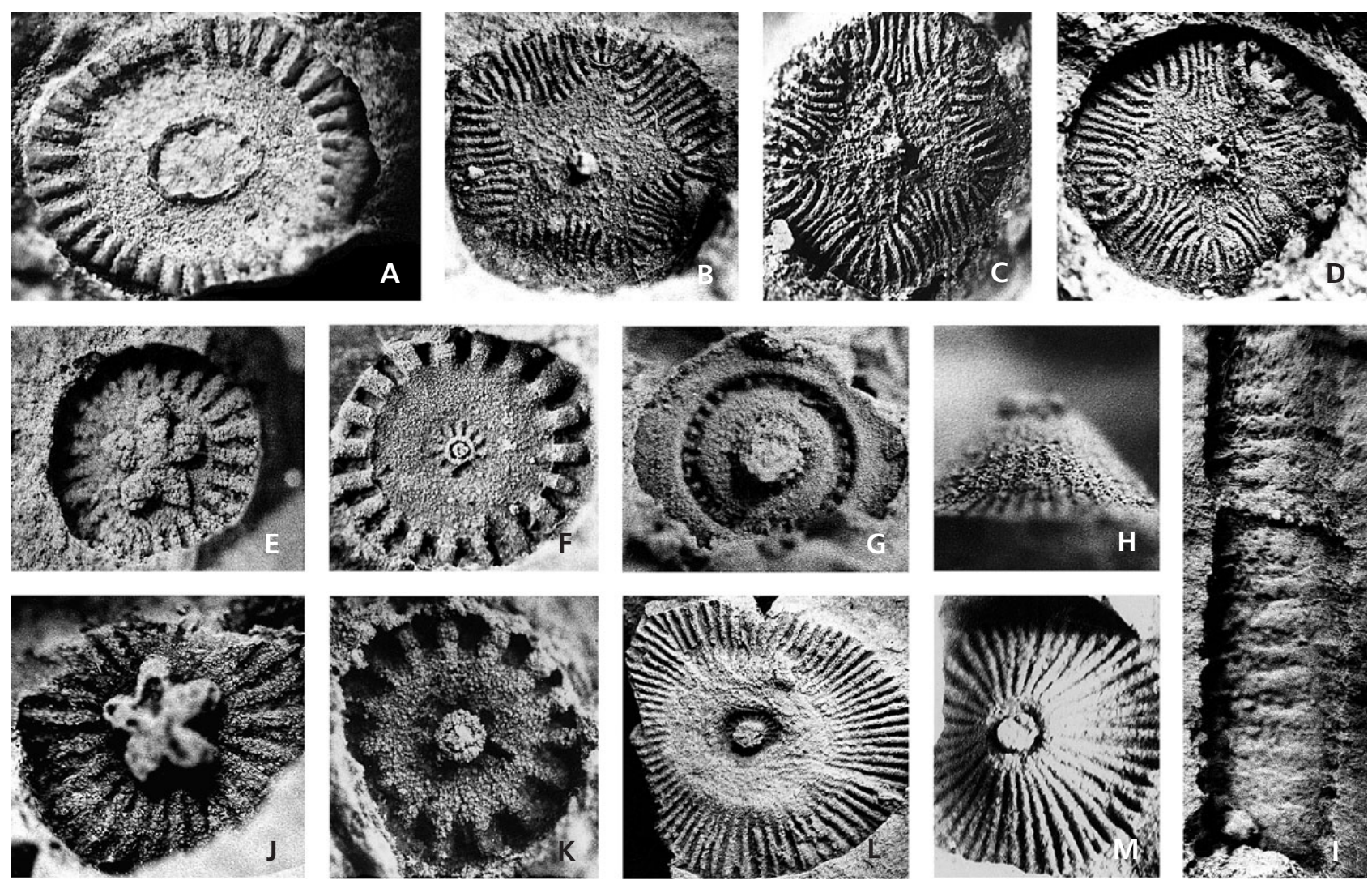

Figure 4. A - Amurocrinus imatschensis (Yeltysheva \& J. Dubatolova, 1961). Not the actual specimen. Exemplar 198/13038, $\times 7$; articular facet of a proximal columnal. Transbaikal, Onon River. Upper Devonian, Beds with Hexacrinites? stukalinae. $\bullet$ B, C, D, I-Ononicrinus gracilis (Yeltysheva \& J. Dubatolova, 1961). B - exemplar 161/13038, × 8; C-exemplar 158/13038, × 7; D - exemplar 160/13038, × 7; articular facets of the proximal columnals. I - exemplar 163/13038, × 4; side view of a stem fragment. Transbaikal, Onon River. Middle Devonian, Beds with Ononicrinus gracilis. - E - Schyschkatocrinus tatyanae Kurilenko, 2002. Not the actual specimen. Holotype 201/13038, × 10; articular facet of a columnal. Transbaikal, Onon River. Upper Devonian, Beds with Hexacrinites? stukalinae. • F, K - Hexacrinites? stukalinae Kurilenko sp. nov. F - holotype 208/13038, × 9; $\mathrm{K}$ - paratype 211/13038, × 16; articular facets of the columnals. Transbaikal, Onon River. Upper Devonian, Beds with Hexacrinites? stukalinae. - G - Amurocrinus conserratus (Yeltysheva \& J. Dubatolova, 1967). Exemplar 216/13038, × 4; articular facets of the proximal columnals. Transbaikal, Onon River. Upper Devonian, Beds with Hexacrinites? stukalinae. $\bullet$ H, M - Asperocrinus paucus Kurilenko, 2000. H - exemplar 222/13038, × 8; M - holotype 3/13037, × 7; articular surfaces of the columnals. Transbaikal, Gazimur River. Upper Devonian, Beds with Hexacrinites? stukalinae. - J - Floricyclus sp. Not the actual specimen. Exemplar 239/13038, × 8; articular facet of a columnal. Transbaikal, Klichka Mountains. Upper Devonian, Beds with Platycrinites? subtuberosus. $\bullet$ L - Hexacrinites? biconcavus Yeltysheva \& J. Dubatolova, 1960. Exemplar 169/13038, $\times 4$; articular facet of a proximal columnal. Transbaikal, Onon River. Middle Devonian, Beds with Ononicrinus gracilis. Type species stored in the Academician F.N. Chernyshev Central Science-Research Geological Exploration Museum (CNIGR Museum), St. Petersburg.

cheehiel (Hou), Mucrospirifer mucronatus (Conrad) and Spinocyrtia martianovi (Stuckenberg), among others, are found in the same layers with the crinoids in Transbaikal. The brachiopod assemblage is composed of taxa typical for the upper parts of the Givetian of the Minusinsk depression, Mongolia, Gorny Altai and the Kuznets Basin. Some species in common, i.e., Eoschuchertella arctostriata (Hall), Devonochonetes coronata (Conrad), Ambocoelia subumbonata (Hall), Mucrospirifer mucronatus (Conrad), are known from the Givetian Hamilton Formation of North America (Hall 1867, Stuckenberg 1886, Hall \& Clarke 1892-1894, Khalfin 1937, Chou 1959, Modzalevskaya 1969, Gratsianova at al. 1987, Goldman \& Mitchell 1990, Kurilenko et al. 2002).
The crinoids of the Upper Devonian of the Russian territory are still poorly known. The Frasnian sequence of the Hexacrinites? stukalinae Biozone in Transbaikal is represented by numerous remains, but some species (Urushicrinus parvulus Kurilenko, U. digitatus Kurilenko, Asperocrinus paucus Kurilenko, Schyschcatocrinus tatyanae Kurilenko) are not known beyond the region (Figs 2, 4, Table 2). The age of the strata is determined by the brachiopods Schizophoria striatula (Schlotheim), Cariniferella carinata (Hall), Productella subaculeata (Murchison), Mucrospirifer mucronatus (Conrad), Cyrtospirifer achmet Nalivkin and Elytha sp. found in these deposits. Schizophoria striatula occurs in the Givetian and Frasnian stages of many regions; 
Cariniferella carinata was reported by Hall \& Clarke (1892-1894) in the Frasnian (Chemungian) deposits of North America; Mucrospirifer mucronatus is most frequently encountered in the Givetian but also occurs in the Frasnian in many regions including eastern Transbaikal; Cyrtospirifer achmet is characteristic for Frasnian deposits of numerous regions. Our stratigraphic analysis of the brachiopod species distribution leads us to conclude that these deposits are of Frasnian age.

Initially the stratum was dated as based on Amurocrinus imatschensis and Hexacrinites? mamillatus (Kurilenko et al. 2002). However, our research has now shown that the first species has a longer range although generally it is very abundant in Frasnian deposits. Regarding the second species, the senior author, as previous researchers, mistakenly identified a specimen, which differs greatly from the holotype and so here, below, we propose a new species of Hexacrinites? stukalinae, which is characteristic for Frasnian deposits.

Famennian crinoids rarely occur in Transbaikal. They are found only in the Teplovskii Suite of the Upper Priamur. Amurocrinus ex gr. imatschensis (Yeltysheva \& J. Dubatolova) is widely distributed in the Devonian sections of Transbaikal. This is the first report of species similar to Bicostulatocrinus circumvallatus (Yeltysheva), which is most abundant in the Upper Famennian and Lower Carboniferous of Transbaikal. Occurring with the crinoids from the Teplovskii Suite listed above, the brachiopods Athyris bajeti Rigaux and Cyrtospirifer verneuili (Murchison) provide evidence of the Famennian age by comparison with Kazakhstan, Kuznetsk Basin (Nalivkin 1930; Khalfin 1932, 1933; Rzhonsnitskaya 1952).

The Platycrinites? subtuberosus Biozone spins the transition from the Devonian to the Carboniferous and yield massive collections in the Transbaikal (Figs 2, 4, Table 2). The fauna of this interval occurs in the sections of the upper part of the Yakovlev Suite (Kotikha Horizon). The crinoid assemblage has a mixed composition and is represented by the co-occurrence of Devonian and Carboniferous species. The representatives of the family Platycrinidae are characteristic for Carboniferous deposits of many Russian regions: Platycrinites? subtuberosus Stukalina, Pl? donicus Kurilenko, Pl? gazimuricus Kurilenko, among others, are most widespread. Besides the Platycrinidae, the typical assemblage is composed of Carboniferous species: Bicostulatocrinus circumvallatus (Yeltysheva), Pentaridica pulcher (Yeltysheva), Florycyclus sp. and Ungulicrinus sp. Devonian crinoids are represented by Anthinocrinus sp. (sensu lato), Asperocrinus sp. and Amurocrinus sp. Representatives of these genera are widespread in Devonian sections of the eastern Urals, Kazakhstan, southern Tian-Shan, Gorny Altai, Salair, and the Far East. A sharp renewal of the taxonomic composition of the crinoid faunas is associated with this biostratigraphic subdivision. Most of the typical Devonian genera disappeared. Genera widely distributed in the Lower Carboniferous occur for the first time.

Sections containing the Platycrinites? subtuberosus Biozone are characterized by the Upper Famennian bryozoan fauna Cyclotrypa arboracea Nekhoroshev, "Stictoporina" bifurcata Nekhoroshev, Monotrypa carbonica Nekhoroshev, Pseudobatostomella longipora (Nekhoroshev), Ipmorella irregularis (Nekhoroshev), Nikiforovella bytchokensis Trizna, Fenestella quadrulla Nekhoroshev and Laxifenestella juxtaserratula Trizna as well as brachiopods Cyrtospirifer ivanovae Beznosova, Tenticospirifer dobroljubovae Beznosova and Sphenospira julii (Dehee). These assemblages allow correlation of deposits with the Abyshevo Horizon (Topkin Unit) of the Kuzbass and the middle subsuite of the Tarkhanskaya Suite of the Rudny Altai (Popeko 2000).

\section{Systematic palaeontology}

Class Crinoidea Miller, 1821

Subclass Camerata Wachsmuth \& Springer, 1885

Order Monobathrida Moore \& Laudon, 1943

Family Hexacrinitidae Wachsmuth \& Springer, 1885

Genus Hexacrinites Austin \& Austin, 1843 (sensu lato)

\section{Hexacrinites? stukalinae Kurilenko sp. nov.} Figure 4F, K

Holotype. - No. 208/13038 (Fig. 4F) is deposited in the CNIGR Museum, St. Petersburg, Russia.

Paratypes. - Nos 211/13038 (Fig. 4K), 205/13038, 209/13038 are deposited in the CNIGR Museum, St. Petersburg, Russia.

Type horizon and locality. - Eastern Transbaikal, Onon River; Upper Devonian, Lower Frasnian, upper part of the Oldoy Horizon, Beds with Hexacrinites? stukalinae.

Material. - Several hundreds of isolated columnals and pluricolumnals.

Etymology. - The name of the species is given in recognition of the many contributions of the paleontologist G. Stukalina.

Diagnosis. - Stem slender homeomorphic, characterized by low, circular holomeric columnals and facet with concave areola; short, wide crenulae; small, pentalobate axial canal, high and wide perilumen. 
Description. - The stem is composed of small ( $\mathrm{D}=2-3 \mathrm{~mm})$ monolithic circular columnals, which are homeomorphic $(\mathrm{h}=0.5-1.0 \mathrm{~mm})$. The areola is central, concave, and smooth. The width of the areola changes depending on the position of the columnal in the stem. Distal columnals have areolae with a width less than one-half the diameter of the columnal; proximal columnals have very wide areolae. All facets bear a narrow crenularium containing numerous short, straight, wide, high, radial crenulae. Costae enlarge greatly to the peripheral edge of the columnal. The length of the costae also depends on the position of the columnal in the stem and changes in proportion to the dimension of the areola. The axial canal is very small (less than $1 \mathrm{~mm}$ ), and pentalobate. A high and rather wide perilumen is situated around the axial canal. The perilumen has minute, radially-disposed denticles.

Remarks. - R. Yeltysheva and G. Stukalina (in manuscripts) and A. Kurilenko (Kurilenko et al. 2002) described the same columnals in the composition of the species Hexacrinites? mamillatus Yeltysheva \& J. Dubatolova. They defined their taxon in open nomenclature (cf., ex gr., aff.). Numerous specimens discovered in the sections of Transbaikal allow recognition of Hexacrinites? stukalinae sp. nov. It is distinguished from $H$ ? mamillatus by the following characters: smaller size of the columnals ( $\mathrm{D}=2-3 \mathrm{~mm}-\mathrm{y}$ Hexacrinites? stukalinae, 5-9 $\mathrm{mm}-\mathrm{y}$ H.? mamillatus); less prominent areola; homeomorphic columnals.

Occurrence. - Eastern Transbaikal, Far East Russia; Upper Devonian, Frasnian, upper part of the Oldoy Horizon, Beds with Hexacrinites? stukalinae.

\section{Summary}

The Devonian deposits of Eastern Transbaikal are represented by two lithofacies within the geological section: carbonate-volcanogenic-terrigenous (Onon terrane) and terrigenous- carbonate (Argun and Upper Amur terranes). In the latter terranes strata are characterized by abundant crinoids and brachiopods. A crinoid biostratigraphic zonation is proposed within the Mongol-Okhotsk fold belt as follows: Scyphocrinites mariannae, Costatocrinus bicostatus and Tastjicrinus paucicostatus (Lower Lochkovian); Amazaricrinus ildicanensis (Pragian); Paradecacrinus orientalis (Emsian); Raricrinus minimus and Vasticrinus vastus (Eifelian); Ononicrinus gracilis (Givetian); Hexacrinites? stukalinae (Frasnian) and Platycrinites? subtuberosus (Upper Famennian). Local and regional crinoid ages accord well with those of brachiopods and lateral distribution of faunal assemblages allows correlation across regions.

\section{Acknowledgements}

The authors are grateful to N. Chaban, the director of "Chitageolsyomka" for constant support of our paleontological investigations and thank E. Modzalevskaya, L. Nebericutina, B. Sokolov and R. Yeltysheva for their identifications. This work has been supported by G. Stukalina. It represents a contribution to UNESCO-IUGS IGCP 499.

\section{References}

Alekseeva, R.E., Mendbajar, B. \& ERlanger, O.A. 1981. Brachiopods and biostratigraphy of Lower Devonian of Mongolia. 176 pp. Nauka, Moscow. [in Russian]

Amantov, V.A. 1963. Stratigraphy and evolution of the Aginskaya structural zone of Transbaikal, 3-14. In SHTAL, N.V. (ed.) Materials for the Geology of the Far East and Transbaikal. 81 pp. Vsesoyuzniy Nauchno-Issledovatel'skiy Geologicheskiy Institut, Leningrad. [in Russian]

ANAShKinA, K.K., Butin, K.S. \& ENIKEEV, F.I. et al. 1997. Geological structure of the Chita region. 239 pp. Chita. [in Russian]

Austin, T. \& Austin, T. Jr. 1843. Description of several new genera and species of Crinoidea. Annals and Magazine of Natural History (series 1) 11(69), 195-207.

BARRANDE, J. 1879. Systême silurien du centre de la Bohême. 226 pp. Published by the author, Prague \& Paris.

Boucot, A.J., JOHNSON, J.G. \& WALMSLEY, V.G. 1965. Revision of the Rhipidomellidae (Brachiopoda; and the affinities of Mendacella and Dalejina). Journal of Paleontology 39(3), 331-334.

CHERnYsheVA, N.E. 1937. About Devonian brachiopods of Mongolia. The works of Mongolian Commission of Academy of Science of the USSR 27(5), 3-56. [in Russian]

CHOU CHUN-PHEY 1959. Devonian brachiopods of North-Eastern China. Acta Palaeontologica Sinica 2, 139-160.

Dubatolova, Y.A. 1971. Crinoidea of the Early and Middle Devonian of the Altai and Kuzbas. Akademiya Nauk SSSR, Sibirskoe Otdelenie Trudy Instituta Geologii i Geofiziki 124, 1-159. [in Russian]

Dubatolova, Y.A. 1982. New species of crinoids of the Shandinsky Horizon of northeast Salair, 73-83. In YUFEREV, O.V. (ed.) Stratigraphy and palaeontology of the Devonian and Carboniferous. Akademiya Nauk USSR, Sibirskoe Otdelenie Trudy Instituta Geologii i Geofiziki 483. Nauka, Novosibirsk. [in Russian]

Dubatolova, Y.A., YeltysheVA, R.S. \& ModZALEVSKaya, E.A. 1967. Devonian and Lower Carboniferous crinoids of the Far East. 72 pp. Nauka, Moscow. [in Russian]

GoldMAN, D. \& MitChELl, C.E. 1990. Morphology, systematics and evolution of Middle Devonian Ambocoelidae (Brachiopoda), Western New York. Journal of Paleontology 64(1), 79-99.

GRACIANOVA, R.T. 1967. Brachiopods and stratigraphy of the Lower Devonian of Mountain Altai. 155 pp. Nauka, Moscow. [in Russian] 
GRACIANOVA, R.T. 1975. Brachiopods of the Early and Middle Devonian of Altai-Sayan region: Strophomenida. $94 \mathrm{pp}$. Nauka, Moscow. [in Russian]

Gratsianova, R.T., TALENT, J.A. \& YAZIKOV, A.Y. 1987. About the systematics and nomenclature of some Spiriferida, which are imported for Devonian Stratigraphy, 102-115. Systematics and phylogeny of fossil invertebrate. Nauka, Moscow. [in Russian]

HALl, J. 1867. Palaeontology of New York. Natural History (New York) 3(15), 1-428.

HALL, J. \& ClaRKe, J.M. 1892-1894. An introduction to the study of the genera of Palaeozoic Brachiopods. Palaeontology of New York 8(1-2), 1-367.

HAVLíČEK, V. 1977. Brachiopods of the order Orthida in Czechoslovakia. Rozpravy Ústředního ústavu geologického 44, $1-327$.

JAHNKE, H. \& SHI YAN 1989. The Silurian-Devonian boundary strata and Early Devonian of the Shidian, Baoshan area (W. Yunnan, China). Courier Forschungsinstitut Senckenberg 110, 137-193.

JoHnSON, J.G. 1970. Great Basin Lower Devonian Brachiopoda, Boulder, Colorado. Geological Society of America Memoir 121, 1-421.

KAPLUN, L.I. 1961. The brachiopods of Lower Devonian of Upper Pribalchash. The Material of Geology and Mineral reserves of Kazakhstan, 64-114. [in Russian]

KHALFIN, L.L. 1932. The Brachiopods of Lower Frasnian of the outskirts Kuznetsk stone coal basin and Gorlovsky coal district. The News of West Siberian Geologorazvedotchny trest 12, 1-52. [in Russian]

KHALFIN, L.L. 1933. Upper Devonian of village Zharkovskoe on the river Jae. $72 \mathrm{pp}$. The works of Coal Institute "Kuzbassugol", Novosibirsk, Moscow \& Leningrad. [in Russian]

KHALFIN, L.L. 1937. Middle Devonian brachiopods in Lebedyansk village of the Angero-Sudgensk region. Izvestiya TII 57(1), 85-148. [in Russian]

KHALFIN, L.L. 1948. Fauna and stratigraphy of the Devonian deposits in Mountain Altay. Izvestiya TPI 65(1), 3-464. [in Russian]

KhAlFin, L.L. 1939. About new genus Rhynchonellida. Soviet Geology 9(12), 83. [in Russian]

KulKov, N.P. \& Peregoedov, L.G. 1989. Stratigraphy of the Lower Devonian deposits of the West-Siberian plate (on data studying of Brachiopods). Geology and Geophysics 1, 3-13. [in Russian]

KulKOV, N.P. \& PeREgOedOV, L.G. 1990. Brachiopods, 70-106. In Stratigraphy of Paleozoic deposits of the southeast of Western-Siberian plate. Nauka, Novosibirsk. [in Russian]

KuRILENKO, A.V. 1989. New Platycrinitidae from the Lower Carboniferous of Eastern Transbaikal area, 128-133. In Kalvo, D.L. (ed.) Fossil and recent echinoderm researches. Akademiya Nauk Estonskoi SSR, Tallinn. [in Russian]

KuRILENKO, A.V., BRETSHTEIN, Y.S. \& BUTIN, K.S. 2001. New Biostratigraphic and Paleomagnetic Data on the Devonian in the Western Mongol-Okhotsk Fold Belt. Geology of Pacific Ocean 16, 1107-1123.

KURILENKO, A.V., KotlyaR, G.V. \& KULKOV, N.P. et al. 2002. Atlas of fauna and flora of the Paleozoic-Mesozoic in the Transbaikal. 714 pp. Nauka, Novosibirsk. [in Russian]

LUCHITSKIY, I.V. 1954. Geological structure of the lower and middle stream of the R. Onon, 3-31. In Essay on the geology of Siberia 17. Nauka, Moscow. [in Russian]

MILLER, J.S. 1821. A natural history of the Crinoidea, or lilyshaped animals; with observations on the genera, Asteria, Euryale, Comatula and Marsupites. 150 pp. Bryan \& Co., Bristol.

ModZalevsKayA, E.A. 1958. Middle Paleozoic of the basin Upper Amur. Informationnyi Sbornik Vsesoyuznogo Nauchno-Issledovatelskii Geologicheskii Institut Trudy 5, 1-8. [in Russian]

ModZAlevsKaya, E.A. 1969. Brachiopods. Class Articulata, 65-127. In ModZalevskoy, E.A. (ed.) Field atlas of Silurian, Devonian and Early Carboniferous Fauna of the Far East. Nedra, Moscow. [in Russian]

MOORE, R.C., JEFFORDS, R.M. \& MILLER, T.H. 1968. Collecting localities, references and index. University of Kansas Paleontological Contributions, Supplement of Echinodermata Articles 8-10, 1-18.

MOORE, R.C. \& LAUDON, L.R. 1943. Evolution and classification of Paleozoic crinoids. Geological Society of America, Special Paper 46, 1-151, 14 pls.

NALIVKIN, D.V. 1930. The brachiopods from Upper and Middle Devonian of Turkestan. 220 pp. Vsesoyuzniy NauchnoIssledovatel'skiy Geologicheskiy Institut, Leningrad. [in Russian]

NALIVKIN, D.V., RZHONSNITSKAYA, M.A. \& MARKOVSKIY, B.P. Eds 1973. Stratigraphy of the USSR. Devonian System. Volume 2. 376 pp. Nedra, Moscow.

RZHONSNITSKAYA, M.A. 1952. Spiriferids from the Devonian. Beds of the Peripheral Areas of the Kuznetsk Coal Basin. 232 pp. Gosgeolizdat, Moscow. [in Russian]

POPEKO, L.I. 2000. Carboniferous of the Mongol-Okhotsk orogenic belt. 124 pp. Dalnauka, Vladivostok. [in Russian]

SCHEWTSCHENKO, T.W. 1966. Crinoids from the Upper Silurian and Lower Devonian deposits of southwestern Tian-Shan and their stratigraphical significance. Upravleniia Geologii Soveta Ministorov Tadzhstan, SSR Trudy, Paleontologiya i Stratigrafiya 2, 123-188. [in Russian]

STUCKENBERG, A. 1886. Materialen zur Kenntniss der Fauna der devonischen Ablagerungen Sibiriens. Memoires de l'Academie imperiale des Sciences de St. Petersbourg, Serie 7, 34(1).

StukAlinA, G.A. 1961. Crinoid stems from Upper Silurian deposits of the Aksarli Mountains (Central Kazakhstan). Informationnyi Sbornik Vsesoyuznogo Nauchno-Issledovatelskii Geologicheskii Institut Trudy 42, 31-42. [in Russian]

StukALINA, G.A. 1964. Ordovician, Silurian, and Early Devonian crinoids from central Kazakhstan and their stratigraphic significance (on basis of study of stems). 20 pp. Avtoreferat dissertation na soskanie rvania kandidata geologomineralogische nauk, Leningrad. [in Russian]

StUKALINA, G.A. 1973. Late Paleozoic crinoids of Transbaikal 
and Mongolia, 16-55. In Pormnov, A.G. \& Suzukov, A.I. (eds) Stratigraphy and Paleontology of the Sedimentary Geological Formations of Transbaikal. Geograficheskoe Obshchestvo SSSR, Zapiski Zabaikalskogo Filiala 94. [in Russian]

STUKALINA, G.A. 1977. New crinoids Devonian from the Urals, Kazakhstan and the Far East, 151-159. In STUKALINA, G.A. (ed.) New species of ancient plants and invertebrates of the USSR, No. 4. Paleontological Institute Akademie Nauk SSSR, Moscow. [in Russian]

StUKALINA, G.A. 1986. Laws of historical development of Crinoidea in the Early and Middle Paleozoic of the USSR. 142 pp. Akademiya Nauk SSSR, Moscow. [in Russian]

STUKALINA, G.A. 1991. Sea lilies of the Lower and Middle Devonian of Kazakhstan, 147-207. In DuBATOLOV, V.N. \& STUKALINA, G.A. (eds) Biostratigraphy of the Lower and Middle Devonian. Akademiya Nauk SSSR, Sibirskoe Otdelenie Institut Geologii i Geofiziki. [in Russian]

TURBIN, M.T. 1994. The Decisions of the Fourth Regional Stratigraphic Conference of Precambrian and Phanerozoic of the Far East south and Transbaikal (Khabarovsk, 1990). 124 pp. Khabarovsk. [in Russian]

TIKHOMIROV, I.N. 1960. Stratigraphy of the Devonian deposits of the territory between the rivers Shilka and Argun. Informationnyi Sbornik Vsesoyuznogo Nauchno-Issledovatelskii Geologicheskii Institut Trudy 38, 19-33. [in Russian]

WAChSMUth, C. \& SPRINGER, F. 1885. Revision of the Paleocrinoidea. Part III, Section 1: Discussion of the classification and relations of the brachiate crinoids and conclusion of the generic descriptions. Proceedings of the Academy of Natural Sciences of Philadelphia for 1885, 225-364.
YAKOVLEV, N.N. 1953. On the discoveries of loboliths in the USSR and their biological significance. Ezhegodnik Vsesoyuznogo Paleontologicheskogo Obshchestva 14, 18-31. [in Russian]

YELTYSHEVA, R.S. 1956. The crinoid stems and their classification. Vestnik Leningradskii Gosudarstvennyi Universitet Seriya Geologischeskaya i Geographicheskaya 2, 40-47. [in Russian]

YELTYSHEVA, R.S. 1957. On a new family of Paleozoic crinoids. Ezhegodnik Vsesoyuznogo Paleontologicheskogo Obshchestva 14, 218-234. [in Russian]

YELTYSHEVA, R.S. 1959. Principles of classification, techniques of study, and stratigraphical significance of crinoid stems. Trudy II sessii Vsesoyuznogo Paleontologicheskogo Obshchestva, 230-235. [in Russian]

YelTYSHEVA, R.S. 1969. Type Echinodermata. Class Crinoidea. Stems of Crinoids, 150-167. In ModZALEVSKOY, E.A. (ed.) Field Atlas of Silurian, Devonian and Early Carboniferous Fauna of the Far East. Nedra, Moscow. [in Russian]

YeltysheVA, R.S. \& DubATOLOVA, Y.A. 1960. New species of Devonian crinoids of the upper Amur, 367-372. In Collected articles on new species of ancient plants and invertebrates of the USSR, pt. II. Vsesoyuznogo Geologicheskii Institut Gosgeoltekhizdat, Moscow. [in Russian]

YeltysheVA, R.S. \& Dubalotova, Y.A. 1961. Crinoids, 294-296, 552-560. In Biostratigraphy of the Paleozoic of the Sayano Altai mountainous country, middle Paleozoic, v. II. Trudy 20. Nauka, Moscow. [in Russian]

ZANINA, I.E. \& LIKHAREV, B.K. Eds 1975. The Stratigraphy dictionary of USSR. Cambrian, Ordovician, Silurian, Devonian. 622 pp. Nedra, Leningrad. [in Russian] 